\title{
Exploring Students' Knowledge and Practice of Digital Citizenship in Higher Education
}

\author{
https://doi.org/10.3991/ijet.v15i19.15611
}

\author{
Ahlam Mohammed Al-Abdullatif $(\bowtie)$ \\ King Faisal University, Al Hassa, Saudi Arabia \\ aalabdullateef@kfu.edu.sa \\ Azza Ali Gameil \\ King Faisal University, Al Hasa, Saudi Arabia
}

\begin{abstract}
The purpose of this study is to investigate undergraduate students' knowledge and practice of eight of the nine elements of digital citizenship: digital commerce, digital communication, digital literacy, digital etiquette, digital law, digital rights and responsibility, digital health and wellness and digital security. The sample population for this descriptive study comprised 204 undergraduate students selected by purposeful sampling. The results show that undergraduate students have an insufficient level of knowledge about good digital citizenship. A significant number of undergraduate students do observe eight digital citizenship elements through several ethical practices; however, the study revealed several concerns among participants in regards to security and safety, such as verifying the reliability and credibility of digital resources, checking the accuracy of information on the Internet, interpreting laws and penalties related to using digital resources, reporting irresponsible behaviour to the appropriate authorities and limiting the time and duration of daily digital device use. The results of this study show that an individual's extent of experience using the Internet is not a factor that affects the level of knowledge and practice of digital citizenship among undergraduate students. Conversely, the nature of academic specialisation, particularly technology-heavy courses (e.g. Educational Technology), are among the factors that affect the knowledge and practice of good digital citizenship. This article offers several recommendations for future study, policy development and practice.
\end{abstract}

Keywords—Digital citizenship, students' knowledge, students' practice, higher education.

\section{Introduction}

Since the emergence of the Internet and related applications, the trend of a large segment of the population using these applications has become known as the digital or electronic revolution. This revolution does not refer to the individual use of a particular website, social networking tools or email, but includes making the Internet and its applications integral to many aspects of daily life such as communication, information 
exchange, public services, commerce, entertainment, social relations, health and education [1]. Despite the positive effects and benefits of the Internet, which has enabled the convenient exchange of information and production of digital content, the same technology has triggered a range of social and ethical issues. Around the world, many concerns and issues have been raised including ranging online safety (identity theft, fraud, hacking and phishing), the misuse of information (plagiarism and illegal access to protected content) and health risks (screen exposure and internet addiction). Many risks accompany the use of the Internet, and this requires that instructors educate students about the benefits of Internet applications while protecting them from its dangers in addition to teaching them about conscientious, safe and effective Internet use. Statistics and studies have found increasing evidence for technology abuse, and it is necessary to develop a preventive policy against the dangers of technology, as well as incentives to encourage responsible use and make the best of its positive qualities. From this standpoint, a new term has emerged, which is gaining momentum and great interest in all parts of the world: digital citizenship [2], [3], [4]. Several developed countries such as Britain, the United States and Canada are currently studying digital citizenship within the framework of the digital education curriculum. Among these efforts are the Australian project 'Connecting with confidence: developing the digital future of Australia', which stipulates the generalization of teaching digital citizenship to students by training parents and teachers according to an integrated national plan, as well as France's plan to make the subject of digital citizenship a major national issue [5].

\section{Research Aim and Significance}

Most previous studies on this subject have focused on measuring or evaluating awareness and knowledge of the elements of digital citizenship among undergraduate students [3], [4], [6], [7]. However, few studies focus on exploring the practice of good digital citizenship as outlined in the literature. Therefore, this study investigates undergraduate students' knowledge and how well they practice eight of the nine elements of digital citizenship including digital commerce, digital communication, digital literacy, digital etiquette, digital law, digital rights and responsibility, digital health and wellness and digital security [8]. This study highlights the topic of digital citizenship concerning the widespread and varying use of digital applications. It contributes to the literature by adding new insights to foundational knowledge, which can be used to develop policies and activities that enable students to practice the elements of good digital citizenship while encouraging desired behaviors and fighting unwanted behaviors. The study aims to draw the attention of those interested in education to the importance of training students in the safe and responsible use of information technology. The recommendations of this study will benefit educational institutions who wish to develop good digital citizenship among their students. 


\section{Research Questions and Hypotheses}

RQ1. To what extent do undergraduate students have knowledge of the concept of digital citizenship?

RQ2. To what extent do undergraduate students implement eight of the nine elements of digital citizenship (digital commerce, digital communication, digital literacy, digital etiquette, digital law, digital rights and responsibility, digital health and wellness and digital security)?

RQ3. Are there any differences in undergraduate students' knowledge and practise of these eight elements of digital citizenship in terms of their academic major and the extent of their experience using the Internet?

Two hypotheses were proposed to answer RQ3 as follows. First hypothesis (H1): There is a significance level of 0.05 in the difference between the means of undergraduate students' responses to statements regarding their knowledge and practice of eight elements of digital citizenship according to students' academic majors. Second hypothesis (H2): There is a significance level of 0.05 in the difference between the means of undergraduate students' responses regarding their knowledge and practice of these eight elements of digital citizenship according to the extent of their experience using the Internet.

\section{$4 \quad$ Literature Review}

\subsection{Digital citizenship and digital citizen characteristics}

The transformation of the ordinary citizen into a digital citizen began in the twentyfirst century when the concept of citizenship became globalized through the concept of the global village, particularly with the great technology revolution resulting in a rapid digital transformation [9], [10]. There are several definitions of digital; the simplest definition is that 'digital citizenship describes the norms of appropriate, responsible behavior with regard to technology use' ([11] p. 15). In addition, Almeslemani [12] states that digital citizenship means preparing and teaching students how to use technological methods in appropriate, safe and sound ways that afford benefits by training students to adhere to positive behavior when using technology. As such, the concept of digital citizenship can take on an educational character in the context of teaching students the skills to use technology in addition to critical thinking skills related to digital content. Another definition outlines digital citizenship as preparing students to deal with technology and protecting them from its risks [13]. Good digital citizenship occurs with the optimal positive use of computers, the Internet, and mobile devices, and will foster a more positive and safer electronic environment for all. Digital citizenship involves an awareness of the digital world and its components, the effective and appropriate practices of using the various mechanisms of the digital world and the ethical rules that make a person's technological behavior socially acceptable when interacting with others [14], [15]. 
Just as individuals must learn to become good citizens within their communities, they need to understand the ethics of digital environments and tools in order to be able to protect themselves, know their rights and become individuals and act intelligently and conscientiously within the digital community. Almekinder et al. [16] use the term 'citizen' to refer to an individual who represents people within society, as society is the contexts in which we live, learn and work. Ribble [11] argues that a digital citizen should have the following characteristics: an understanding of human, cultural and social issues related to technology and the practice of legal and ethical behavior; advocacy for the practice of safe, legal and responsible use of information and technology; the demonstration of a positive attitude toward the use of technology that supports collaboration, learning and productivity; a sense of responsibility for their life-long learning; a commitment to intellectual honesty; respect for different cultures and societies in the virtual environment; and the preservation of personal information. A digital citizen should also manage their time spent using technology and must protect themself from corrupt harmful information that can spread across online media [11]. A digital citizen is one who regularly and effectively uses the Internet [17]; they are an ethical individual who manages their actions and consequences and who understands the risks and benefits of easy access to information [18], [19].

\subsection{Digital citizenship and educational systems}

The concept of digital citizenship is tied strongly to educational systems because it helps teachers understand what a student must know to use technology appropriately. Digital citizenship is more than just an educational tool: it is a way to prepare students for full participation in society and active participation in serving the interests of the nation in the digital environment [20]. Alqayed [5] indicates that the dimensions of digital citizenship lay the foundations, principles and strategies of teaching and learning that elevate behaviour and correctly establish the rules of digital security (selfprotection) and combating cybercrime. As well as promoting intellectual property concepts and adherence to them, integrity and the foundations of scientific documentation, research ethics through extracurricular courses and activities [21]. Educational institutions must offer instruction on digital citizenship to enable students to engage with the digital world and to provide students with a framework of knowledge and training opportunities to help them understand the impact of the digital revolution on their lives, as well as how to interact positively and safely [22].

Educational systems play a role in helping students to develop these foundations. Educational institutions should also develop teaching and learning strategies that are established with goals related to the encouragement of moral values and the balance between behavior and maturity of personality, as well as the promotion and development of higher-order thinking skills, especially critical thinking, in order to help students exercise caution and avoid conveying and re-sending suspicious or misleading ideas in digital environment. Aldahshan [14] indicates the importance of laying the foundations of responsible digital consumption, awareness of fraud and security risks, and healthy relationships with technology from both physical and mental health perspectives. Extracurricular activities also play a role, with part of students' education 
directed towards preparing them to work in the digital community. The introduction of digital citizenship and its elements in some courses at different levels of education, especially in universities, will contribute greatly to the acquisition of these skills [21].

Recent studies have found teacher and student knowledge of some aspects of digital scholarship to be lacking and, therefore, recommend more training for teachers and the provision of core courses related to digital citizenship for university students. One assessed how aware teachers and students at Harvest International School were about the elements of digital citizenship [7]. This study revealed that participants were moderately aware of the elements of digital citizenship. Participant awareness of digital law was significantly different from awareness of digital rights and responsibilities. This difference suggests that teachers and learners are not prepared for their duty as responsible digital citizens. A lack of awareness of privacy settings was the main concern of the respondents. In a study based in the Kingdom of Saudi Arabia, Mahrous [23] found that there was a significant lack of knowledge about digital citizenship among kindergarten teachers. The study by Alselehat et al. [4] aimed to identify degrees of awareness of the concept of digital citizenship among undergraduate students in the Faculty of Educational Sciences at the University of Jordan. They concluded that the degree of student awareness is average and recommended that students should be made aware of advanced methods of protection from the risks of participating in the internet community, such as dealing with cases of electronic penetration. Likewise, Alsamadi [24] found that Qassim University students' perceptions of digital citizenship and the ways to apply them in educational institutions were moderate. Academic specialization appears to affect students' perceptions of digital citizenship; therefore, several studies emphasized introducing a course on digital citizenship as a core required course at the undergraduate level [3], [25], [26].

Previous studies have been concerned with identifying the degree of awareness of the concept and elements of digital citizenship among students [1], [3], [4], [6], [7]. The current study reveals the extent of both the knowledge and practice of digital citizenship elements and considers whether demographic factors such as academic major and extent of experience using the Internet affect the knowledge and practice of the elements of digital citizenship. These previous studies informed the study questionnaire design and are also used to frame the results of this study.

\section{Conceptual Framework}

Teaching digital citizenship involves preparing individuals for a technology-heavy society by giving them different technical skills and training them to adhere to standards of acceptable behavior when using technology in the home, at school or elsewhere. To understand digital citizenship and issues related to the use of technology nine elements of digital citizenship have been identified to help outline how citizens work with each other in a global digital society [8]:

Digital access strives for equal opportunities to full electronic participation in society for all individuals. Electronic exclusion makes it difficult for individuals to achieve growth and prosperity; hence, the starting point for digital citizenship is to 
work towards providing equal digital rights and supporting electronic access for all. The goal of the digital citizen should be to work to provide and expand access to technology for others.

Digital commerce refers to the buying and selling of goods online. Technology users must understand that the largest part of the market economy exists through technological channels. Hence, legal and legitimate exchanges take place at the same time as illegal and illegitimate ones, and it is, therefore, necessary to develop an awareness of the controls to which an individual must adhere [2]. According to Mossberger et al. [17], students should be aware of the dangers associated with buying online. Unless they understand how to defend themselves from scams and know how to recognize safe payment and sites that securely maintain information, as opposed to those that do not, they will be easy prey in online commerce environments. Awareness, education and action are required in order to give students a base of knowledge about the rules for digital behavior so that they may safely and responsibly buy and sell merchandise in digital marketplaces [27].

Digital communication refers to the electronic exchange of information and an individual's ability to invest themselves in digital technologies by communicating with others. Email, mobile phones and instant messages offer widespread digital communication options that have changed human lives due to the ability to make permanent and direct contact with almost anyone at almost any time [28].

Digital literacy refers to one's ability to use technology efficiently, to interpret and understand digital content, to assess its credibility and to research and communicate information with the appropriate tools [29]. It has become an individual and social responsibility that everyone must observe to provide learning and training opportunities. The focus must be renewed to center on the type of technology that must be acquired, learned and trained, as well as optimal methods of instruction [30].

Digital etiquette refers to the standards of behavior or procedure expected by other users of digital technology [28]. Many technology users do not learn 'digital fitness' before using it. Usually, some regulations and laws are imposed on users, or technology is banned to stop inappropriate use. However, the enactment of regulations and the formulation of employment policies alone are not sufficient. Each user must be educated and trained to be a responsible digital citizen independent of formal rules.

Digital laws refer to the digital regulations that technology users agree to indicate that they understand the legal rights and restrictions that govern the use of technology. Thus, digital law requires understanding and awareness [31]. Unethical users may engage in theft or digital crime, while ethical users adhere to the laws of the digital community. Users must know that stealing or misusing the property, business, or identity of others via the Internet is a crime under the law; there are several laws enacted by the digital community that punish people who misuse the Internet. Hacking into other people's information, illegally downloading their files, creating and disseminating destructive viruses or spyware and stealing another person's identity or property are all acts of crime.

Digital rights and responsibilities are the benefits extended to all users of technology and the behavioral expectations that come with the freedoms that everyone enjoys in the digital world. Digital citizens enjoy a set of rights, including expectations of 
privacy and freedom [28]. These rights come with duties and responsibilities, and users must cooperate when determining the proper use of technology. These two concepts work together so that every digital citizen may become a productive citizen of and an active participant in the digital community. Students should be made aware of these rights and responsibilities and should be given a base of knowledge, the rules of ethical behavior and basic legal concepts to support them in a digital society [27].

Digital health and safety refer to the maintenance of mental and physical wellbeing in the world of digital technology [15], [28]. Symptoms of repeated stress and auditory practices are among the most important issues that must be addressed, and users must be made aware of these concerning the use of technology. As one example, eye problems are a physical issue associated with computer use. Users ought to adhere to the recommended session length, ensure that their eyes are properly aligned with the computer screen and maintain an appropriate distance from the computer. These behaviors reduce the risk of eye fatigue [27].

Finally, digital security refers to the procedures used to ensure electronic protection, such as installing antivirus programs, creating backup copies of data and providing targeted control software and hardware, in order to protect our information from any external force that may try to access data illicitly [32], [33].

Although the International Association for Technology in Education (ISTE) presents valuable criteria for students, teachers, administrators and others interested in the educational process regarding the appropriate technology use, there is currently no general agreement on the specific behaviors to be followed when using digital technology. Therefore, attention has been given to the ethics and responsibilities of digital use. It was agreed that the aim of educational institutions should be to train individuals in the responsible, ethical and safe use of information and communication technology (ICT) as members of society and citizens of the global community [34]. It is vital to instill the values of responsible ICT use among students and to develop positive attitudes towards technological applications that support lifelong learning, cooperation, personal motivation and productivity [7], [20], [25], [35]. Therefore, this study aims to understand better undergraduate students' knowledge and practice of digital citizenship based on eight of the nine elements of digital citizenship [8]. Since the focus of this study is on Saudi Arabia, where digital access is not an issue among undergraduate students, the digital access element was not included in this study.

\section{$6 \quad$ Methodology}

The present study, conducted at King Faisal University (KFU) in Saudi Arabia, assesses undergraduate students' knowledge and practice of eight of the nine elements of digital citizenship. A descriptive survey approach was used to obtain information from undergraduate students about their characteristics, opinions, attitudes, selfreported beliefs and behaviors concerning this concept [36], [37]. A survey questionnaire was developed for this study and included two sections. The first section asked participants to indicate general demographic information regarding their academic specialty and the extent of their Internet use. The second section presented 43 state- 
ments related to the eight elements of digital citizenship. This section instructed participants to indicate their perceived level of knowledge and practice of digital citizenship by responding to the statements on a five-point Likert scale ranging from 'strongly disagree' to 'strongly agree'. The validity of the questionnaire was assured by submitting it to a group of experts in the field who checked each statement for language accuracy and whether the statements were appropriate for study subject and purpose. The experts strongly approved of the questionnaire in general and suggested modifications were made before the questionnaire was finalized. The reliability of the survey was calculated using Cronbach's alpha. Cronbach's alpha coefficient was 0.988, which indicates the high reliability of the questionnaire.

\subsection{Participants and procedures}

The target population of this study was undergraduate students at KFU in the Bachelor of Education program. Participants were female students from four different academic specialties: Childhood Education, Special Needs Education, Art in Education and Educational Technology. Participants were between 18 and 26 years old.

\subsection{Procedure (Data collection and analysis)}

Data were collected by the end of the 2019-2020 academic year. The survey questionnaire was electronically distributed to 204 undergraduate students via emails from their instructors. The descriptive analysis provided comprehensive insights into the participants' perceptions of knowledge and practice. Chi-square (X2) statistical analysis was used to identify which of the questionnaire statements were more statistically significant than others within each of the eight elements of digital citizenship. A oneway ANOVA was performed to locate statistical differences in the knowledge and practice of digital citizenship according to different academic majors and levels of experience using the Internet. Scheffe's coefficient was used to detect where the significance lay and which groups it favored. For the one-way ANOVA test, the 0.05 alpha level was used as the criterion for statistical significance. Data in this study were analyzed using SPSS V23. The results are discussed in the following section.

\section{$7 \quad$ Results and Discussion}

Table 1 lists demographic information concerning participants' academic majors and the extent of their experience using the Internet. As shown in Table 1, most participants specialized in Educational Technology (57.5\%) and had more than ten years of experience using the Internet (45\%). In general, the participants considered themselves as being experienced with various digital technologies (ICTs). 
Table 1. Demographic information of participants by academic major and extent of experience using the Internet $(\mathrm{N}=204)$

\begin{tabular}{|l|c|c|}
\hline \multicolumn{1}{|c|}{ Academic Major } & Number & \% \\
\hline \multicolumn{1}{|c|}{ Experience Using the Internet } & & \\
\hline Educational Technology & 117 & 57.4 \\
\hline Childhood Education & 68 & 33.3 \\
\hline Art Education & 4 & 7.4 \\
\hline Special Needs Education & $\mathbf{2 0 4}$ & 2.0 \\
\hline Total & & $\mathbf{1 0 0}$ \\
\hline \multicolumn{1}{|c|}{31} & 15.2 \\
\hline 1-6 years & 73 & 35.8 \\
\hline 7-10 years & 100 & 49.0 \\
\hline More than 10 years & $\mathbf{2 0 4}$ & $\mathbf{1 0 0}$ \\
\hline Total & &
\end{tabular}

In response to RQ1, Table 2 describes the participants' perceptions of their knowledge about the concept of digital citizenship. Descriptive statistics, represented as percentages, were used to quantify participants' responses to five statements from the questionnaire.

Table 2. Student participants' knowledge of digital citizenship ( $N=204)$

\begin{tabular}{|l|c|c|c|}
\hline \multicolumn{1}{|c|}{ Statements } & \% I don't agree & \% to some extent & \% I agree \\
\hline $\begin{array}{l}\text { I am knowledgeable about the concept } \\
\text { of digital citizenship. }\end{array}$ & 85.3 & 8.8 & 5.9 \\
\hline $\begin{array}{l}\text { I am knowledgeable about the elements } \\
\text { relating to digital citizenship. }\end{array}$ & 95.1 & 4.9 & 0.0 \\
\hline $\begin{array}{l}\text { I know what digital access and commu- } \\
\text { nication are and their importance. }\end{array}$ & 26.5 & 0.0 & 73.5 \\
\hline $\begin{array}{l}\text { I am aware of how to interact with } \\
\text { digital technologies and devices. }\end{array}$ & 2.9 & 7.8 & 89.2 \\
\hline $\begin{array}{l}\text { I know how to handle my personal } \\
\text { digital data. }\end{array}$ & 0.0 & 9.3 & 90.7 \\
\hline
\end{tabular}

Table 2 shows that most participants did not agree that they were knowledgeable about the concept of digital citizenship (85.3\%), and more than $95 \%$ were not aware of the elements of digital citizenship. These results may be due to the recent emergence of the concept and indicate that students need more education about the elements of digital citizenship. This result is supported by several studies [4], [9], [15], [23], [38]. On the other hand, most of the participants agreed that they had sufficient knowledge about digital access and communication, as well as the importance of these concepts $(73.5 \%)$. The majority also agreed that they knew how to consciously interact with digital technology and devices (89.2\%) and that they knew how to handle their personal digital data $(90.7 \%)$. These results are supported by [25].

RQ2 asked how participants perceived their practice of the eight elements of digital citizenship. X2 analysis of independence and relatedness was used to identify which 
of the questionnaire statements were more statistically significant than others within each of the eight elements of digital citizenship. In terms of the digital commerce element, Table 3 shows the participants' responses to six statements regarding digital commerce. The results in Table 3 demonstrate significant statistical differences in the frequencies of all six statements included in the digital commerce element $(\mathrm{p}<0.05)$.

Table 3. Student participants' perceptions of their practice of digital commerce $(\mathrm{N}=204)$

\begin{tabular}{|l|c|c|c|c|c|c|c|c|}
\hline \multicolumn{1}{|c|}{ Digital Commerce } & \multicolumn{3}{|c|}{ Frequency } & \multicolumn{2}{|c|}{$\mathbf{X}^{2}$} & \multicolumn{1}{|c|}{ df } & Sig. \\
\hline Statements & 1 & 2 & 3 & 4 & 5 & \multicolumn{3}{|c|}{} \\
\hline $\begin{array}{l}\text { I interact with many applications for the purposes of buying and } \\
\text { selling online. }\end{array}$ & 39 & 25 & 9 & 27 & 104 & 133.5 & 4 & .000 \\
\hline I check the security of commercial websites before use. & 49 & 50 & 14 & 24 & 67 & 45.06 & 4 & .000 \\
\hline I deal with popular commercial sites when buying online. & 2 & 4 & 0 & 16 & 182 & 540.9 & 3 & .000 \\
\hline $\begin{array}{l}\text { I read the commercial website's policy and information in a careful } \\
\text { manner. }\end{array}$ & 14 & 154 & 10 & 6 & 20 & 395.2 & 4 & .000 \\
\hline $\begin{array}{l}\text { I verify the reliability and credibility of the commercial site before } \\
\text { use. }\end{array}$ & 75 & 40 & 7 & 32 & 50 & 60.65 & 4 & .000 \\
\hline I delete promotional commercial messages sent to my email. & 51 & 29 & 9 & 47 & 68 & 97.64 & 4 & .000 \\
\hline
\end{tabular}

Participants rated their responses as strongly agree for statements 1 and 3, disagree for statement 4 , and strongly disagree for statements 2, 5 and 6 . These responses indicate that participants interacted considerably with commercial websites and digital applications to buy and sell online; however, they were not sure of the websites' security, nor were they familiar with the websites' policies. This result highlights serious issues facing undergraduate students in Saudi Arabia regarding appropriate practices of digital commerce requirements such as unconscientious use and ignorance of eprocurement policies, which may expose students to electronic fraud. This result aligns with recent findings on the insufficient practice of security and safety measures among digital citizens [15], [23]. The results, therefore, indicate the need to provide students with more of understanding and practicing good cybersecurity [9].

Table 4 shows the participants' perceptions of five statements regarding digital communication. These results indicate significant statistical differences in the frequencies of four of the statements $(1,3,4$, and 5) regarding the digital commerce element $(p<0.05)$. There was no variance in participants' responses to statement 2 . The participants' rated their responses primarily as agree and strongly agree for all five statements. This result indicates that participants share and interact with others considerably using different ICT tools and applications (e.g. social media, emails, and mobile applications) for both personal and academic purposes. This result signifies the high level of digital communication and interaction among undergraduate students via digital means [39]. Kara [15] argues that a high level of digital communication and interaction represents the level of social involvement in cultural exchange. It is crucial to increase students' skills regarding safe and appropriate digital interactions, particularly when communicating their ideas and resources. Copyright and openresource licenses (e.g. Creative Commons) are two important concepts that should be included in courses on digital citizenship. 
Table 4. Student participants' perceptions of their practice of digital communication $(N=204)$

\begin{tabular}{|l|c|c|c|c|c|c|c|c|}
\hline \multicolumn{1}{|c|}{ Digital Communication } & \multicolumn{3}{c|}{ Frequency } & \multicolumn{3}{c|}{$\mathbf{X}^{\mathbf{2}}$} & df & Sig. \\
\hline Statements & 1 & 2 & 3 & 4 & 5 & \multicolumn{3}{|c|}{} \\
\hline I use ICTs to communicate and share ideas with others. & 0 & 0 & 0 & 4 & 200 & 1888.3 & 1 & .000 \\
\hline I use digital social media to communicate with others. & 0 & 0 & 0 & 102 & 102 & .000 & 1 & 1.00 \\
\hline I share audio and video clips in my Internet interactions. & 1 & 7 & 3 & 6 & 187 & 655.4 & 4 & .000 \\
\hline $\begin{array}{l}\text { I use the Internet to support activities inside and outside the } \\
\text { university. }\end{array}$ & 1 & 6 & 3 & 25 & 169 & 512.5 & 4 & .000 \\
\hline I use email to communicate with others. & 12 & 19 & 3 & 20 & 150 & 369.8 & 4 & .000 \\
\hline
\end{tabular}

Table 5 shows participants' responses to three statements regarding their digital literacy. These results show significant statistical differences in the frequencies of all three statements related to digital literacy $(\mathrm{p}<0.05)$. Most participants rated their responses as strongly agree for statements 1 and 3 . This result indicates that undergraduate students have high levels of motivation and determination to learn and master digital technologies. Additionally, this result signifies undergraduates' awareness of the inherent risks of the excessive use of ICTs. For statement 2, participants' responses were approximately equal between agree and strongly agree (50\%) and between disagree and strongly disagree (49\%). Although this indicates that some undergraduate students were careful when using ICTs in terms of verifying reliability and credibility, there were still some students who lacked this level of caution. This result confirms the results presented in Table 3.

Table 5. Student participants' perceptions of their practice of digital literacy $(\mathrm{N}=204)$

\begin{tabular}{|l|c|c|c|c|c|c|c|c|}
\hline \multicolumn{1}{|c|}{ Digital Literacy } & \multicolumn{3}{c|}{ Frequency } & \multicolumn{3}{|c|}{$\mathbf{X}^{\mathbf{2}}$} & df & Sig. \\
\hline Statement & 1 & 2 & 3 & 4 & 5 & \multicolumn{3}{|c|}{} \\
\hline I try to learn and master ICTs before using them. & 30 & 12 & 3 & 20 & 139 & 305.2 & 4 & .000 \\
\hline $\begin{array}{l}\text { I check the accuracy of information and evaluate different sources } \\
\text { on the Internet. }\end{array}$ & 23 & 78 & 0 & 33 & 70 & 43.09 & 3 & .000 \\
\hline I learn about the inherent risks involved in overusing ICTs. & 11 & 2 & 0 & 75 & 116 & 172.6 & 3 & .000 \\
\hline
\end{tabular}

Table 6 shows participants' perceptions of five statements regarding digital etiquette. The results show significant statistical differences in the frequencies of two of the statements $(1$ and 2$)$ related to the digital etiquette element $(\mathrm{p}<0.05)$. Statements 3,4 and 5 show no variance in participants' response frequencies. Most participants rated their responses as agree to strongly agree for all five statements. 
Table 6. Student participants' perceptions of their practice of digital etiquette $(\mathrm{N}=204)$

\begin{tabular}{|c|c|c|c|c|c|c|c|c|}
\hline Digital Etiquette & & & equ & Iency & & $\mathbf{X}^{2}$ & df & Sig. \\
\hline Items & 1 & 2 & 3 & 4 & 5 & & & \\
\hline $\begin{array}{l}\text { I do not share my personal information on social media and other } \\
\text { ICTs. }\end{array}$ & 4 & 2 & 0 & 24 & 174 & 401.3 & 3 & .000 \\
\hline $\begin{array}{l}\text { I adhere to rules relating to polite dialc } \\
\text { various ICTs. }\end{array}$ & 1 & 0 & 0 & 5 & 198 & 372.9 & 2 & .000 \\
\hline $\begin{array}{l}\text { counts that contain inappropriate messa } \\
\text { y, religion, or public taste). }\end{array}$ & 0 & 0 & 0 & 102 & 102 & 0.000 & 1 & 1.00 \\
\hline I do not exchange offensive digital content via ICTs. & 0 & 0 & 0 & 102 & 102 & 0.000 & 1 & 1.00 \\
\hline $\begin{array}{l}\text { In my use of different ICTs, I respect the views a } \\
\text { others and accept people's differences. }\end{array}$ & 0 & 0 & 0 & 102 & 102 & 0.000 & 1 & 1.00 \\
\hline
\end{tabular}

This result suggests that participants consistently applied digital etiquette practices when using ICTs. This result signifies that undergraduates adhered to the rules of digital etiquette such as sharing personal information, dialogue and conversation, adequately dealing with inappropriate messages, exchanging offensive content and respecting others' opinions. This result is supported by [25].

Table 7 shows participants' perceptions of four statements regarding their knowledge and practice of digital law. These results indicate significant statistical differences in the frequencies of all four statements included in the digital law element ( $\mathrm{p}<0.05$ ). Most participants rated their responses as strongly agree for statement $1(94 \%)$ and statement $3(98 \%)$. This result indicates a high level of respect for users' online rights, such as security of identity and privacy of information. However, most participants rated their responses as disagree or strongly disagree for statement 2 $(75 \%)$, and statement $4(61 \%)$. This result highlights a low level of knowledge related to interpreting laws and penalties issued by government agencies in the fight against digital crimes, including copyright rules and the illicit sharing of digital resources licenses. This result also corresponds with the results presented in Table 3 and emphasizes a critical need for university students to learn how to apply digital law to their online activities to be good digital citizens. The same result was highlighted by several studies, including [15] and [40]. These results also support claims by [7] regarding the importance of training, seminars and workshops dealing with digital law, safety and security.

Table 7. Student participants' perceptions of their practice of digital law $(\mathrm{N}=204)$

\begin{tabular}{|l|c|c|c|c|c|c|c|c|}
\hline \multicolumn{1}{|c|}{ Digital Law } & \multicolumn{3}{|c|}{ Frequency } & \multicolumn{2}{c|}{$\mathbf{X}^{\mathbf{2}}$} & \multicolumn{1}{|c|}{ df } & Sig. \\
\hline Items & 1 & 2 & 3 & 4 & 5 & \multicolumn{3}{|c|}{} \\
\hline I respect others on the Internet and do not abuse their rights. & 0 & 0 & 0 & 12 & 192 & 158.8 & 1 & .000 \\
\hline $\begin{array}{l}\text { I read about the laws and related penalties regarding government } \\
\text { agencies' fight against information-related crimes. }\end{array}$ & 86 & 66 & 3 & 21 & 28 & 114.3 & 4 & .000 \\
\hline $\begin{array}{l}\text { I do not use hacking software or steal other people's identity or } \\
\text { private information. }\end{array}$ & 4 & 0 & 0 & 0 & 200 & 188.3 & 1 & .000 \\
\hline $\begin{array}{l}\text { I adhere to electronic licenses and copyright rules and acknowledge } \\
\text { the work of others when I use their digital materials. }\end{array}$ & 101 & 25 & 5 & 33 & 40 & 127.9 & 4 & .000 \\
\hline
\end{tabular}


Table 8 indicates participants' responses to four statements regarding their digital rights and responsibilities. These results show significant statistical differences in the frequencies of all four statements included in the digital rights and responsibilities element $(\mathrm{p}<0.05)$. Most participants rated their responses as strongly agree for statement 1 (99\%) and statement $3(99 \%)$. This result indicates that undergraduate students' sense of responsibility related to following access policies and digital rules of ethics. This result is supported by Mahdi [1], who observed a high level of ethical use among users in the digital world. However, most participants rated their responses as disagree or strongly disagree for statement $4(50 \%)$. This result might be due to undergraduates' insufficient knowledge about the importance of this practice or even how to report the irresponsible behavior that they see online properly. This result might be attributable to the failure of educational institutions to increase students' awareness and skills related to this critical issue. In terms of statement 3 , although most of the participants rated their responses as agree or strongly agree $(69 \%)$, others disagreed with this statement $(31 \%)$. These results confirm those presented in Table 7 , as well as recent observations of low levels of good digital rights practices among young citizens [7].

Table 8. Student participants' perceptions of their practice of digital rights and responsibilities $(\mathrm{N}=204)$

\begin{tabular}{|l|c|c|c|c|c|c|c|c|c|}
\hline \multicolumn{1}{|c|}{ Digital Rights and Responsibilities } & \multicolumn{3}{|c|}{ Frequency } & \multicolumn{3}{c|}{$\mathbf{X}^{\mathbf{2}}$} & df & Sig. \\
\hline Items & 1 & 2 & 3 & 4 & 5 & \multicolumn{3}{|c|}{} \\
\hline I adhere to the acceptable access policies of competent authorities. & 0 & 0 & 0 & 1 & 203 & 200.02 & 1 & .000 \\
\hline I adhere to digital laws and agreed regulations. & 51 & 12 & 0 & 92 & 49 & 62.86 & 3 & .000 \\
\hline I adhere to the rules of ethics regarding the digital world. & 0 & 1 & 0 & 1 & 202 & 396.1 & 2 & .000 \\
\hline $\begin{array}{l}\text { I report irresponsible behaviours, such as threats, extortion, and } \\
\text { abuse, to the appropriate authorities. }\end{array}$ & 49 & 54 & 11 & 26 & 64 & 46.25 & 4 & .000 \\
\hline
\end{tabular}

Table 9 shows participants' responses to six statements regarding digital health and safety. These results indicate significant statistical differences in the frequencies of all six statements included in digital health and safety $(\mathrm{p}<0.05)$. Most participants rated their responses as agree or strongly agree for statement $1(93 \%)$, statement $5(83 \%)$ and statement $6(91 \%)$. This result suggests that participants were aware of and did apply physical health and safety practices in their use of ICTs.

However, their disagreement with statement $3(83 \%)$ and statement $4(71 \%)$ might indicate poor time management when using digital devices. This lack of knowledge may further result in excessive use (at any time and any place), which can negatively impact health and safety. Participants appeared not to agree with statement 2 regarding the addictive risks associated with the excessive use of ICTs: $48 \%$ agreed, and $52 \%$ disagreed with this statement. In addition to the participants' perceptions that their addiction to digital devices was not a threat to their health, those who were aware of the risks may not know how to minimize them. 
Table 9. Student participants' perceptions of their practice of digital health and safety

$$
(\mathrm{N}=204)
$$

\begin{tabular}{|l|c|c|c|c|c|c|c|c|}
\hline \multicolumn{1}{|c|}{ Digital Health and Safety } & \multicolumn{3}{|c|}{ Frequency } & \multicolumn{2}{c|}{$\mathbf{X}^{\mathbf{2}}$} & df & Sig. \\
\hline Items & 1 & 2 & 3 & 4 & 5 & \multicolumn{3}{|c|}{} \\
\hline I am aware of the physical effects of sustained use of ICTs. & 0 & 0 & 0 & 14 & 190 & 151.8 & 1 & .000 \\
\hline I realise the danger of ICTs addiction and how to reduce its impact. & 35 & 71 & 0 & 18 & 80 & 50.71 & 3 & .000 \\
\hline I commit to using digital devices at specific times during the day. & 105 & 64 & 0 & 17 & 18 & 104.5 & 3 & .000 \\
\hline $\begin{array}{l}\text { I adhere to the correct setting while using the computer or mobile } \\
\text { devices. }\end{array}$ & 86 & 60 & 0 & 28 & 30 & 44.63 & 3 & .000 \\
\hline $\begin{array}{l}\text { I ensure that lighting on the computer screen and workplace is appro- } \\
\text { priate to reducing eyestrain. }\end{array}$ & 18 & 15 & 0 & 56 & 115 & 127.6 & 3 & .000 \\
\hline $\begin{array}{l}\text { I get breaks and do physical exercise while working on the computer } \\
\text { or other digital devices. }\end{array}$ & 11 & 7 & 0 & 89 & 97 & 139.1 & 3 & .000 \\
\hline
\end{tabular}

Table 10 indicates participants' perceptions of six statements regarding their practice of digital security. These results show significant statistical differences in the frequencies of all six statements included in the digital security element $(p<0.05)$. Most of the participants expressed disagreement with all six statements. This result indicates that undergraduate students are unaware of the security issues involved in engaging with digital spaces. These digital security issues may be mitigated using antivirus software, firewall and spyware protection software, updating operating systems and the use of spam filters. Similarly, a low level of digital security has been observed in several studies on young digital citizens and represents a serious concern to educators [7], [15], [23], [39]. Participant responses also indicated that students are not engaging in activities to raise awareness among their family members or friends who use ICTs, which is due to their own lack of awareness and practices of digital security.

Table 10. Student participants' perceptions of their practice of digital security

$$
(\mathrm{N}=204)
$$

\begin{tabular}{|l|c|c|c|c|c|c|c|c|}
\hline \multicolumn{1}{|c|}{ Digital Security } & \multicolumn{3}{|c|}{ Frequency } & \multicolumn{2}{|c|}{$\mathbf{X}^{\mathbf{2}}$} & dff & Sig. \\
\hline Items & 1 & 2 & 3 & 4 & 5 & \multicolumn{3}{|c|}{} \\
\hline I purchase antivirus software for my devices. & 108 & 57 & 0 & 18 & 21 & 103.4 & 3 & .000 \\
\hline I periodically update the operating system on my devices. & 81 & 40 & 0 & 13 & 70 & 55.41 & 3 & .000 \\
\hline $\begin{array}{l}\text { I download and update the latest spyware protection software for my } \\
\text { computers and devices. }\end{array}$ & 76 & 43 & 0 & 14 & 71 & 48.19 & 3 & .000 \\
\hline I use a spam filter for incoming emails and messages. & 122 & 68 & 0 & 4 & 10 & 180.8 & 3 & .000 \\
\hline I ensure that the operating system's firewall software is always running. & 78 & 58 & 3 & 17 & 48 & 91.34 & 4 & .000 \\
\hline I work to spread awareness among members of my family who use ICTs. & 126 & 55 & 0 & 6 & 17 & 172.9 & 3 & .000 \\
\hline
\end{tabular}

RQ3 asked whether significant differences in undergraduate students' knowledge and practice of the eight elements of digital citizenship were affected by their academic major or the extent of their experience using the Internet. Two hypotheses were proposed as responses to RQ3: 
H1. There is a significance level of 0.05 in the difference between the means of undergraduate students' responses regarding their knowledge and the practice of the eight elements of digital citizenship according to students' academic majors.

H2. There is a significance level of 0.05 in the difference between the means of undergraduate students' responses regarding their knowledge and the practice of the eight elements of digital citizenship according to the extent of their experience using the Internet.

Table 11 lists a comparison of means (with Standard Deviation) for participants' responses regarding their knowledge and practice of digital citizenship according to their academic major and the extent of their experience using the Internet. In both the knowledge and practice categories, the mean response of participants' who specialized in Educational Technology $(\mathrm{M}=2.27)$ was higher than that of those who specialized in other majors.

Table 11. A comparison of means (with Standard Deviation) for participants' academic major and extent of experience using the Internet in terms of digital citizenship knowledge and practice $(\mathrm{N}=204)$

\begin{tabular}{|l|c|c|}
\hline & Knowledge & Practice \\
\hline Academic major & $M(S D)$ & $M(S D)$ \\
\hline Educational Technology & $2.27(.131)$ & $3.89(.201)$ \\
\hline Childhood & $2.06(.134)$ & $3.51(.219)$ \\
\hline Art Education & $1.71(.198)$ & $3.46(.199)$ \\
\hline Special Needs Education & $1.75(.191)$ & $3.14(.602)$ \\
\hline Internet use experience & & \\
\hline 1-6 years & $2.10(.230)$ & $3.66(.267)$ \\
\hline 7-10 years & $2.14(.220)$ & $3.74(.296)$ \\
\hline More than 10 years & $2.17(.215)$ & $3.72(.314)$ \\
\hline
\end{tabular}

However, in terms of participants' extent of experience using the Internet, these results do not show significant variance in responses in either the knowledge or practice category.

Regarding the first hypothesis (H1), there was a statistical significance level of 0.05 between the means of participants' responses regarding their knowledge and practice of eight digital citizenship elements according to their academic majors. Table 12 shows the results of a one-way ANOVA test. The one-way ANOVA test reported statistically significant differences between the response means of participants with different academic majors $(\mathrm{p}<0.05)$ concerning the two digital citizenship factors: knowledge and practice. We, therefore, accept the first hypothesis. 
Table 12. Differences in the means of students' perceptions of digital citizenship knowledge and practice according to academic major groups, using one-way ANOVA $(\mathrm{N}=204)$

\begin{tabular}{|l|l|c|c|c|c|c|}
\hline \multicolumn{2}{|c|}{ Academic major } & Sum of Squares & df & Mean Square & F & Sig. \\
\hline \multirow{4}{*}{ Knowledge } & Between groups & 5.951 & 3 & 1.984 & \multirow{2}{*}{102.836} & $.000^{*}$ \\
\cline { 2 - 5 } & Within groups & 3.858 & 200 & 0.019 & & \\
\cline { 2 - 5 } & Total & 9.809 & 203 & & & \\
\hline \multirow{3}{*}{ Practice } & Between groups & 8.882 & 3 & 2.961 & \multirow{2}{*}{01.921} & $.000^{*}$ \\
\cline { 2 - 5 } & Within groups & 9.562 & 200 & 0.048 & & \\
\cline { 2 - 5 } & Total & 18.44 & 203 & & & \\
\hline
\end{tabular}

*Indicates significance at $\mathrm{p}<0.05$

Table 13 shows the location of significance among each academic major group, as well as which groups are favored using the Scheffe coefficient. Regarding knowledge of good digital citizenship, there were statistically significant differences between the response means of the students who specialized in Educational Technology ( $\mathrm{M}=$ 2.27) and the students who specialized in Special Needs Education $(M=1.75)$, Art Education $(\mathrm{M}=1.71)$ and Childhood Education $(\mathrm{M}=2.06)$.

Likewise, in terms of practices of good digital citizenship, Table 13 shows that there were statistically significant differences between the response means of the students who specialized in Educational Technology $(M=3.89)$ and the students who specialized in Special Needs Education $(\mathrm{M}=3.14)$, Art Education $(\mathrm{M}=3.46)$ and Childhood Education $(M=3.51)$. These results indicate that the students who specialized in Educational Technology were more aware of the eight elements of digital citizenship and were better able to apply them to their online activities. This result may be due to their attitudes towards Internet use or to the nature of their academic major, which includes many courses concerned with digital interaction and the use of ICTs. This result agrees with Alsamadi [24] and Ke and Xu [40]. Al-Zahrani [41] also found that attitudes towards Internet use and self-efficacy are important factors that influence student practices of digital citizenship.

Table 13. Multiple comparisons between academic major groups using the Scheffe coefficient $(\mathrm{N}=204)$

\begin{tabular}{|l|l|c|c|c|}
\hline \multirow{5}{*}{ Knowledge } & \multicolumn{1}{c|}{ Groups } & $\begin{array}{c}\text { Special Needs } \\
\text { Education }\end{array}$ & $\begin{array}{c}\text { Art } \\
\text { Education }\end{array}$ & Childhood \\
\cline { 2 - 5 } & Educational Technology & $.000^{*}$ & $.000^{*}$ & $.000^{*}$ \\
\cline { 2 - 5 } & Childhood & $.000^{*}$ & $.000^{*}$ & - \\
\cline { 2 - 5 } & Art Education & .959 & - & - \\
\hline \multirow{3}{*}{ Practice } & Educational Technology & $.000^{*}$ & $.000^{*}$ & $.000^{*}$ \\
\cline { 2 - 5 } & Childhood & .014 & .919 & - \\
\cline { 2 - 5 } & Art Education & .074 & - & - \\
\hline
\end{tabular}

*The mean difference is significant at the 0.05 level

In terms of testing the second hypothesis (H2), there was not a statistical significance at the level of 0.05 between the means of participants' responses regarding their knowledge and practice of digital citizenship according to the extent of participants' 
experience using the Internet. Table 14 shows the results of a one-way ANOVA test, which compared the means of the different groups of Internet use experience for each of the two digital citizenship factors: knowledge and practice.

Table 14. Differences in the means of students' digital citizenship knowledge and practice according to Internet use experience groups, using one-way ANOVA ( $\mathrm{N}=204)$

\begin{tabular}{|c|c|c|c|c|c|c|}
\hline Inte & Use Experience & Sum of Squares & df & Mean Square & $\mathbf{F}$ & Sig. \\
\hline \multirow{3}{*}{ Knowledge } & Between groups & 0.142 & 2 & 0.071 & \multirow{3}{*}{1.480} & \multirow{3}{*}{.230} \\
\hline & Within groups & 9.667 & 201 & \multirow{2}{*}{0.048} & & \\
\hline & Total & 9.809 & 203 & & & \\
\hline \multirow{3}{*}{ Practice } & Between groups & 0.161 & 2 & 0.080 & \multirow{3}{*}{0.883} & \multirow{3}{*}{.415} \\
\hline & Within groups & 18.28 & 201 & \multirow{2}{*}{0.091} & & \\
\hline & Total & 18.44 & 203 & & & \\
\hline
\end{tabular}

*The mean difference is significant at the 0.05 level

The results reveal no statistically significant differences between the response means of participants at $\mathrm{p}<0.05$ concerning either factor of digital citizenship. This result suggests that the extent of students' experience using the Internet is not a determining factor in their knowledge or practice of good digital citizenship. We, therefore, reject the second hypothesis. This result agrees with Alselehat et al. [4], but disagrees with Alqahtani [42], who observed that the extent of students' experience using the Internet does affect their knowledge and practice of good digital citizenship.

\section{Conclusion and Recommendations}

This study investigated undergraduate students' knowledge and practice of eight of the nine elements of digital citizenship: digital commerce, digital communication, digital literacy, digital etiquette, digital law, digital rights and responsibility, digital health and wellness and digital security [8]. This study has shown that, although the majority of undergraduate student participants had more than ten years of experience using the Internet and agreed that they had sufficient knowledge about how to access and interact with digital technologies and devices, they lacked sufficient knowledge of good digital citizenship concept and several of its elements. Digital commerce appears to be the area with the highest level of access and interaction; however, participants showed an insufficient level of practicing digital security and safety when buying and selling online. Sharing and exchanging information and knowledge, for personal and academic purposes, through different digital means and applications was another area in which participants demonstrated a high level of digital competence. In general, the results of this study demonstrated a significant level of competence in undergraduate students' practices related to digital literacy, digital etiquette, digital law, digital rights and responsibilities, and digital health and safety. The participants generally indicated agreement with ethical practices such as the appropriate handling and sharing of personal digital data, respect for others' privacy, acknowledging other points of views and following the digital policies for access, electronic licensing and copyright. Additionally, student participants were significantly committed to learning and mastering 
various forms of digital technologies, as well as educating themselves about the physical and psychological risks of overusing digital technologies. On the other hand, this study has highlighted several concerns among participants in regards to security and safety such as verifying the reliability and credibility of websites or other digital resources, checking the accuracy of information obtained from the Internet, interpreting the laws and penalties related to using digital resources, reporting irresponsible behavior to the appropriate authorities and the inability to control oneself by limiting the time and duration spent using digital devices.

Although the results of this study showed that the extent of undergraduate students' experience using the Internet is not one of the factors that affect their knowledge and practice of good digital citizenship, their academic specialization, particularly technology-heavy courses such as Educational Technology, is a factor that affects their knowledge and practice of good digital citizenship. These findings indicate that the knowledge and practice of good digital citizenship are not developed solely using digital technologies and that the dimensions and elements of this concept must be strategically studied and taught to undergraduate students. Therefore, an important implication of this study for policy and curriculum development in higher education institutions is the inclusion of digital citizenship as a core required course at the undergraduate level. It will be necessary to review other university programs and specific courses to identify opportunities to include instruction on the elements of digital citizenship both theoretically and practically based on a clear vision and strategies. Moreover, higher education institutions should conduct training programs, workshops and seminars for both faculty members and students on digital citizenship and its applications to support learning related to becoming a responsible digital citizen.

It is recommended that educational institutions establish workshops to develop students' knowledge and practice on the basics of buying and selling online, on the importance of understanding the security certifications of any online shopping website, on the rules of network behavior, on how to consciously resist unsafe or inaccurate information, on how to evaluate and select reliable sources of information and on how to verify the authenticity of published material. It is suggested that these seminars and workshops also deal with digital law, safety and security in order to acquaint students with the procedures of informing appropriate authorities about criminal violations of digital laws. In addition to introducing students to the elements of security, seminars and workshops that explain the physical and psychological risks associated with the use of technology, and ways to mitigate these risks, are recommended. This study recommends that future research should investigate the critical factors that influence undergraduate students' practices of good digital citizenship. More studies are needed to examine the role of social networks in influencing the values of digital citizenship. Finally, more analytical studies are required to analyze core courses in higher education to evaluate the degree to which the concept and elements of digital citizenship are embedded, both theoretically and practically. 


\section{$9 \quad$ References}

[1] H. R. Mahdi, 'The awareness of the digital citizenship among the users of social networks and its relation to some variables', International Journal of Learning Management Systems, vol. 6, no. 1, pp. 11-25, 2018. https://doi.org/10.18576/ijlms/060102

[2] K. D. Alhosary, 'The level of knowledge of a social studies teacher with the dimensions of digital citizenship and its relationship to some variables', The Arab Journal for Educational and Social Studies, vol, 8, pp. 89-141, 2016.

[3] M. W. Almasry and A. H. Shaath, 'The level of digital citizenship of a sample of Palestine university students from their point of view', Palestine University Journal for Research and Studies, vol. v7, no. 2, pp. 171-203, 2013.

[4] Y. R. Alselehat, F. R. Alfalloh and A. K. Alsarhan, 'The degree of awareness of the concept of digital citizenship for undergraduate students in the Faculty of Educational Sciences at the University of Jordan', Dirasat: Educational Sciences, vol. 45, no. 3, pp. 19-33, 2018.

[5] M. Alqayed, 'The concept of digital citizenship', 2014. Retrieved from https://www.neweduc.com/definition-of-digital-citizenship

[6] A. A. Alsuhaim and A. A. Alibrahim, 'The extent to which computer teachers activate the digital citizenship standards in the secondary school', Specialized Educational Journal, vol. 8, no. 4, pp. 1-12, 2019.

[7] R. L. Suson, 'Appropriating digital citizenship in the context of basic education', International Journal of Education, Learning and Development, vol. 7, no. 4, pp. 44-66, 2019.

[8] M. S. Ribble, G. D. Bailey and T. W. Ross, 'Digital citizenship: addressing appropriate technology behaviour', Learning \& Leading with Technology, vol. 32, no. 1, pp. 6-12, 2004.

[9] K. R. Al Rashed, 'Future perspective to improve the level of digital citizenship among the Jordanian university students', Journal of Educational and Psychological Sciences, vol. 3, no. 23, pp. 1-22, 2019.

[10] M. Saputra and I. H. Al Siddiq, 'Social media and digital citizenship: The urgency of digital literacy in the middle of A disrupted society era', International Journal of Emerging Technologies in Learning (iJET), vol. 15, no. 7, pp. 156-161, 2020. https://doi. org/10.3991/ijet.v15i07.13239

[11] M. Ribble, 'Passport to digital citizenship', Learning \& Leading with Technology, vol. 36, no. 4, pp. 14-17, 2008.

[12] L. E. Almeslemani, 'Learning and digital citizenship: a proposed vision', Education World Journal, vol. 2, no. 47, pp. 15-94, 2014.

[13] A. F. Alshehri, 'The family challenge in promoting the values of digital citizenship: a proposed vision, 2016. Retrieved from https://repository.nauss.edu.sa J. A.

[14] Aldahshan, 'Digital citizenship as an introduction to Arab education in the digital age', Journal of Criticism and Enlightenment, vol. 5, no. 2, pp. 72-104, 2016.

[15] N. Kara, 'Understanding university students' thoughts and practices about digital citizenship: a mixed methods study', Journal of Educational Technology \& Society, vol. 21, no. 1, pp. 172-185, 2018.

[16] A. Almekinder et al., 'Digital citizenship + liberal arts = students empowered for life', Educause Review, 2017. Retrieved from https://er.educause.edu:443/articles/2017/6/ digital-citizenship-liberal-artsstudents-empowered-for-life 
[17] K. Mossberger, C. J. Tolbert and A. Hamilton, 'Broadband adoption| measuring digital citizenship: mobile access and broadband', International Journal of Communication, vol. 6, no. 37, pp. 2492-2528, 2012.

[18] J. B. Ohler, Digital community, digital citizen. Thousand Oaks, CA: Corwin Press, 2010.

[19] K. Mossberger, C. J. Tolbert and R. S. McNeal, Digital citizenship: The Internet, society, and participation. Cambridge, MA: MIT Press, 2007.

[20] U. Başarmak, H. Yakar, E. Güneş and Z. Kuş, 'Analysis of digital citizenship subject contents of secondary education curricula', Turkish Online Journal of Qualitative Inquiry, vol. 10, no. 1, pp. 26-51, 2019.

[21] A. M. Alhesan, 'For a safe intellectual balance: the foundations of digital citizenship in your classroom', Journal of Knowledge, vol. 9, 2015.

[22] H. H. Aljazzar, 'The role of the educational institution in inculcating the values of digital citizenship: a proposed vision', Journal of Arabic Studies in Education and Psychology, vol. 36, no. 2933, pp. 1-34, 2014.

[23] G. K. Mahrous, 'The level of knowledge of kindergarten teachers in the Kingdom of Saudi Arabia in the dimensions of digital citizenship', Journal of Scientific Research in Education, vol. 19, pp. 117-147, 2018.

[24] H. S. Alsamadi, 'Qassim university students' perceptions of digital citizenship and ways to activate it in educational institutions: a field study on a sample of Qassim University students', Journal of Research Studies, vol. 9, no. 27, pp. 141-160, 2017.

[25] N. M. Nassar, 'Perceptions of Arab Open University students in the Kingdom of Saudi Arabia towards digital citizenship and ways to enhance it: a field study on a sample of university students', Journal of the Islamic University of Educational and Psychological Studies, vol. 27, no. 1, pp. 152-184, 2019.

[26] H. Altwalbah, 'Digital citizenship in national and civil education books: an analytical study', Jordanian Journal of Educational Sciences, vol. 13, no. 3, pp. 209-308, 2017.

[27] R. Hollandsworth, L. Dowdy and J. Donovan, 'Digital citizenship in K-12: it takes a village', TechTrends, vol 55, no. 4, pp. 37-47, 2011. https://doi.org/10.1007/s11528-0110510-Z

[28] T. M. Almallah, Digital citizenship. Egypt: Assahab Publishing and Distribution, 2017.

[29] A. C. Sense, Digital literacy and citizenship in the 21st century. San Francisco, CA: Common Sense Media, 2009.

[30] A. Couros and K. Hildebrandt, Digital citizenship education in Saskatchewan schools, Saskatchewan Ministry of Education, 2015. Retrieved from http://publications.gov.sk.ca/ documents/11/83322-DC\%20Guide\%20-\%20ENGLISH\%202.pdf

[31] M. Ribble, Digital citizenship in schools: nine elements all students should know. Washington, DC: International Society for Technology in Education, 2015.

[32] H. B. Giddour, 'The impact of the digital revolution and the extensive use of social networks in drawing the new image of the concept of citizenship: from the ordinary citizen to the digital citizen', The Books of Law, vol. 15, pp. 720-735, 2016.

[33] M. S. Ribble and G. D. Bailey, 'Digital citizenship focus questions for practice', Learning \& Leading with Technology, vol. 32, no. 2, pp. 12-15, 2004.

[34] W. Shehatah, 'The nine elements of digital citizenship', 2013. Retrieved from https://doi. org/10.1007/3-540-26620-8_28

[35] N. Selwyn, Digital technology and the contemporary university: degrees of digitisation. London: Routledge, 2014.

[36] P. Leedy and J. Ormrod, Practical research: planning and design, $8^{\text {th }}$ ed. Upper Saddle River: Pearson, 2005. 
[37] L. Neuman, Social research methods: qualitative and quantitative approaches. USA: Pearson, 2006.

[38] M. Assayed, 'The role of new media in supporting digital citizenship for university students', Journal of Public Relations Research in Middle East, vol. 12, pp. 99-161, 2016.

[39] L. M. Jones and K. J. Mitchell, 'Defining and measuring youth digital citizenship', New Media \& Society, vol. 18, no. 9, pp. 2063-2079, 2016. https://doi.org/10.1177/1461444815 $\underline{577797}$

[40] D. Ke and S. Xu, 'A research on factors affecting college students' digital citizenship', in 2017 International Conference of Educational Innovation through Technology (EITT), IEEE, Dec. 2017, pp. 61-64. https://doi.org/10.1109/eitt.2017.23

[41] A. Al-Zahrani, 'Toward digital citizenship: examining factors affecting participation and involvement in the Internet society among higher education students', International Education Studies, vol. 8, no. 12, pp. 203-217, 2015. https://doi.org/10.5539/ies.v8n12p20 $\underline{3}$

[42] A. S. Alqahtani, 'The extent to which the values of digital citizenship are included in the teaching techniques course from the viewpoint of faculty members', Journal of the Islamic University of Educational and Psychological Studies, vol. 26, no. 1, pp. 57-97, 2018.

\section{Authors}

Ahlam Mohammed Al-Abdullatif is an assistant professor in educational technology at King Faisal University in Saudi Arabia. Al-Abdullatif's research interest is in eLearning particularly on how Information and Communication Technology (ICT) enhances teaching and learning practices. She is an active professor and researcher, who published several research articles with well-known publishers such as Taylor and Francis and Springer. Al-Abdullatif won the 2017/2018 Faculty Excellence Award at King Faisal University and the 2017/2018 E-learning Excellence Award from the National Centre of E-learning in Saudi Arabia.

Azza Ali Gameil is an assistant professor in educational technology at King Faisal University, Saudi Arabia. She is an active professor and researcher. Gameil's research interest focuses on technological innovations and the use of digital technologies in education along with instructional design.

Article submitted 2020-05-15. Resubmitted 2020-06-30. Final acceptance 2020-07-02. Final version published as submitted by the authors. 